In "The Black Sea Flood Question: Changes in Coastline, Climate, and Human Settlement", Valentina Yanko-Hombach, Allan S. Gilbert, Nicolae Panin and Pavel M. Dolukhanov, ISBN 978-1-40204774-9

\title{
Water-level fluctuations in the Black Sea since the Last Glacial Maximum
}

\author{
Gilles Lericolais ${ }^{1}$, Irina Popescu ${ }^{2}$, Francois Guichard ${ }^{3}$, Speranta-Maria Popescu ${ }^{4}$ and \\ Laurence Manolakakis ${ }^{5}$
}

\footnotetext{
${ }^{1}$ IFREMER, Institut Francais de Recherche pour l'Exploitation de la Mer Centre de Brest, 70, F29200 Plouzané cedex, France

${ }^{2}$ RCMG, Renard Centre of Marine Geology Department of Geology and Soil Science, University of Ghent, Krijgslaan 281 s.8, B-9000 Gent, Belgium

${ }^{3}$ LSCE, Laboratoire des Sciences du Climat et de l'Environnement, CNRS-CEA, Avenue de la Terrasse, 1, F 91198 Gif-sur-Yvette cedex, France

${ }^{4}$ Centre de Paléontologie Stratigraphique et Paléoécologie, Université Claude Bernard - Lyon 1, 43, blvd du 11 Novembre 1918, F69622 Villeurbanne cedex, France

${ }^{5}$ UMR, Unité Mixte de Recherche, 7041 CNRS Equipe Protohistoire européenne, 21 Allée de I'Université, F92023 Nanterre cedex, France
}

\begin{abstract}
:
Two IFREMER oceanographic surveys carried out in the northwestern Black Sea in 1998 and 2002 complement previous seabed mapping and subsurface sampling by various international expeditions. They show that the lake level rose on the continental shelf to at least the -40 to $-30 \mathrm{~m}$ isobath based on the landward limit of a Dreissena layer representative of very low salinity conditions $(<5 \%)$. The Black Sea then shows clear evidence for an onset of marine conditions at 7150 BP. From these observations, Ryan et al. (1997) concluded that the Black Sea could have filled abruptly with saltwater cascading in from the Mediterranean. Despite critical discussions of this interpretation, recent IFREMER discoveries of well preserved drowned beaches, sand dunes, and soils appear to lend support to the flood hypothesis. This new evidence includes (1) multibeam echo-sounding and seismic reflection profiles that reveal wave-cut terraces at about $-100 \mathrm{~m}$, (2) Romanian shelf cores that show an erosion surface indicating subaerial exposure well below the sill of the modern Bosphorus, (3) 14C ages documenting a colonization of the former terrestrial shelf surface by marine molluscs at $7150 \mathrm{BP}$, (4) evidence of sea water penetration into the Black Sea in the form of recent canyon heads at the Bosphorus outlet, and (5) palynological analysis and dinocyst studies that pinpoint the arrival of freshwater during the Younger Dryas and, later, the rapid replacement of Black Sea dinocysts by a
\end{abstract}


Mediterranean population.

Keywords: $\quad$ Rapid transgression, Younger Dryas, Seismic stratigraphy, multibeam geomorphology, Bosphorus outlet, Black Sea continental shelf

\section{INTRODUCTION}

In 1997, Ryan and Pitman (Ryan et al. 1997) presented astonishing evidence supporting a catastrophic flooding of the Black Sea basin about 7500 years ago and speculated on the role it may have played in the spread of early farming into Europe and much of Asia. Their book, Noah's Flood, The New Scientific Discoveries About The Event That Changed History (Ryan and Pitman 1998), proposed that the Black Sea flood could have cast such a long shadow

over succeeding cultures that it inspired the deluge account in the Babylonian epic of Gilgamesh and, in turn, the story of Noah in the Book of Genesis.

This hypothesis resulted from a joint Russian-American expedition conducted in 1993 on the continental shelf south of the Kerch Strait (Major 1994; Ryan et al. 1997). High-resolution seismic reflection profiles, cores precisely targeted on these profiles, and ${ }^{14} \mathrm{C}$ accelerator mass spectrometry (AMS) dating of recovered fauna permitted several conclusions. The survey revealed a buried erosional surface strewn with shelly gravel that extended across the broad continental margin of the northern Black Sea and beyond the shelf break (Evsylekov and Shimkus 1995; Major 1994). The cores reveled evidence of subaerial mud cracks at $99 \mathrm{~m}$ beneath the sea surface, algal remains at $110 \mathrm{~m}$, and in situ roots of shrubs in desiccated mud at $\sim 123 \mathrm{~m}$. Each site lay well below the 70 m depth of the Bosphorus bedrock sill (Algan et al. 2001; Gökaşan et al. 1997).

The combined evidence suggested to the research team that a drowning event in the Pontic basin may have resulted from a marine transgression into a vastly shrunken lake. It appeared that this inundation subsequently deposited a uniform drape of marine mud upon the former terrestrial surface, creating a sapropel layer equally thick in depressions as on crests of dunes, and with no sign of landward-directed onlap of the sedimentary layers in the drape (Ryan et al. 2003). The ${ }^{14} \mathrm{C}$ age determinations documented a simultaneous subaqueous colonization of the terrestrial surface by marine molluscs at $7100 \mathrm{BP},{ }^{1}$ and this date was assigned to the flooding event.

The previous shrunken lake stage and subsequent flooding preclude the possibility of outflow to the Sea of Marmara at that time. Recently, however, Aksu et al. (2002c) presented arguments for persistent Holocene outflow from the Black Sea to the eastern Mediterranean and for non-catastrophic variations in the level of the Black Sea during the last 10,000 years (Aksu et al. 2002a). 
These findings are in direct contradiction to the flood hypothesis.

In 1998 and 2002, two Black Sea projects, one European and the other more broadly international, enabled IFREMER to conduct two oceanographic surveys that afforded the opportunity to complete work previously begun on seabed mapping and subsurface sampling. The main objectives of these cruises were to prepare for the European ASSEMBLAGE Project, which would assess Black Sea sedimentation since the Last Glacial Maximum (LGM), quantify the impacts of climate change, and evaluate the sensitivity of the Black Sea system to external forcing. Progress in resolving these major issues can be achieved only through examination of geomorphology and stratigraphy from the shelf to the abyssal deep in the northwestern corner of the Black Sea.

These surveys revealed that lake level in the Pontic basin rose on the shelf to at least the -40 to $-30 \mathrm{~m}$ isobath, which corresponds to the landward limit of a layer containing the shelly debris of Dreissena rostriformis distincta, a mollusc indicative of freshwater conditions. This rise in freshwater suggests that the lake which preceded the formation of the Black Sea served as an important catchment for meltwater draining out of the Fennoscandian ice cap: Melt Water Pulse 1A during the Bölling-Allerød interval (Bard et al. 1990). Possibly, the lake level at this time broke over the sill of its outlet and spilled into the Mediterranean through the Marmara Sea, however, the onset of salt water conditions creating the Black Sea during the mid-Holocene (7150 BP) has been clearly demonstrated. Although opposing hypotheses have been proposed (Aksu et al. 1999b, 2002a, b, c), recent discoveries of well preserved drowned beaches, sand dunes, and soils provide new evidence supporting the Ryan and Pitman flood hypothesis.

\section{GEOLOGICAL BACKGROUND}

The Black Sea is a $2.2 \mathrm{~km}$ deep basin with a wide continental shelf in its northwestern corner (Figure 1). External connection to the Mediterranean Sea is over a sill within the Bosphorus Strait. The role played by this strait in controlling the salinity and stratification of both seas as well as the production of anoxia in the Black Sea has been often discussed (Arkhangel'sky and Strakhov 1938; Scholten 1974; Muramoto et al. 1991; Rohling 1994; Lane-Serff et al. 1997; Abrajano et al. 2002). The general view is that during periods of low global sea level, the connection between the Black Sea and the ocean was severed. The Black Sea then freshened as a result of continued river discharge, expanding into a vast, well ventilated lake with a shoreline established at the level of its outlet (Chepalyga 1984; Hodder 1990), from which excess water was exported to the Mediterranean. 


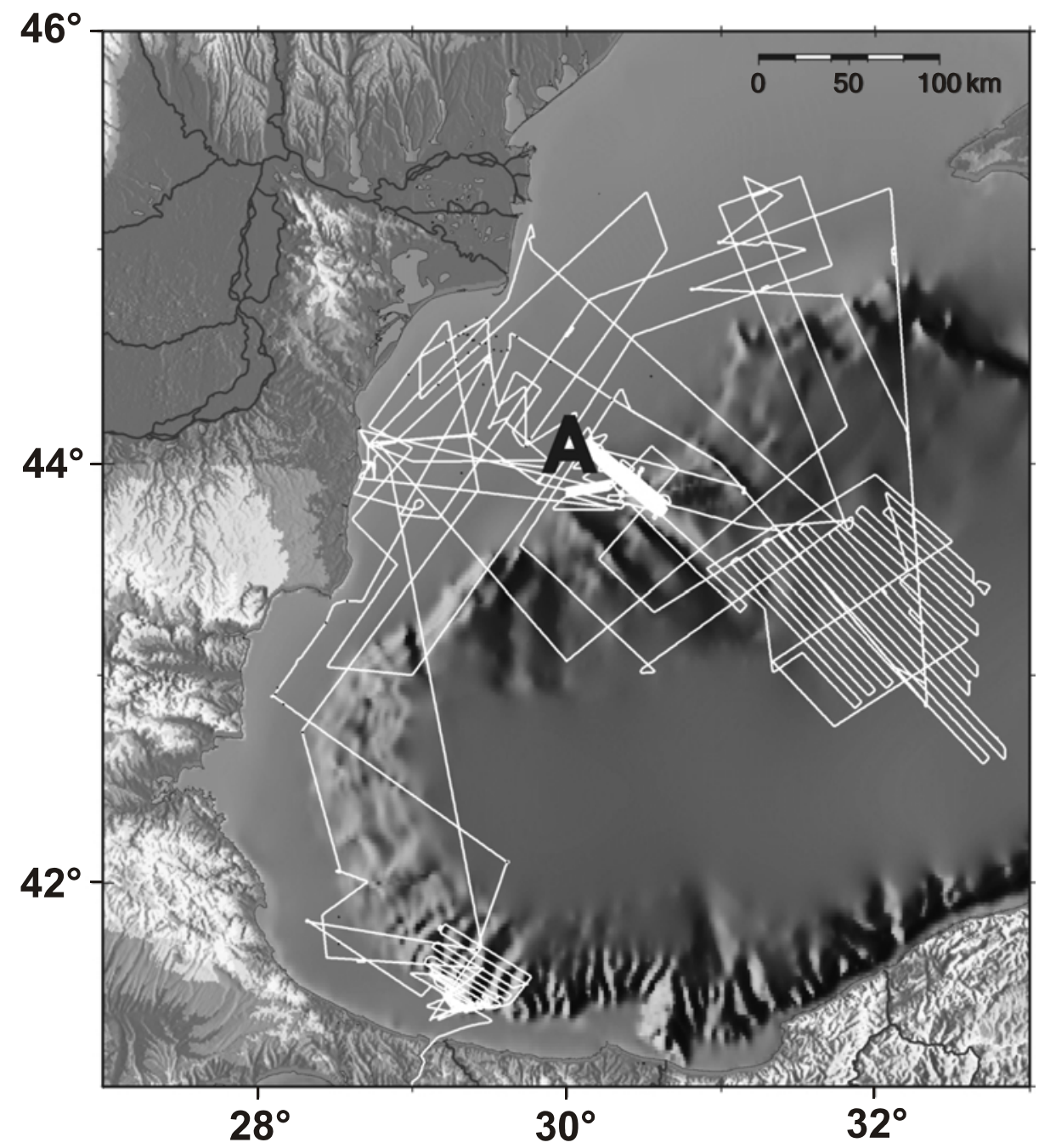

Figure 1. Bathymetry of the semi-enclosed Black Sea basin and IFREMER survey route locations. “A” represents location depicted in Figure 3.

The largest European rivers, the Danube, Dnieper, and Dniester, deliver their water and deposit their sediment loads into the northwestern Black Sea. The Danube drainage basin, 817,000 $\mathrm{km}^{2}$ in areal extent, charges the Black Sea at an estimated rate of $6047 \mathrm{~m}^{3} / \mathrm{s}$ (almost $190 \mathrm{~km}^{3} / \mathrm{yr}$ ), while the river's sediment discharge at its mouth was about 51.7 million tons per year $(\mathrm{t} / \mathrm{yr})$ before the river was dammed in 1970 and 1983 (Bondar 1998). Estimates of total sediment discharge subsequent to damming average less than 30-35 million t/yr, of which only 4-6 million t/yr is sandy material (Panin 1997). During glacial lowstands, and especially at the beginning of interglacials, sediment discharge from these 
rivers was probably much higher.

It has long been recognized that the Black Sea became isolated from the Marmara and Mediterranean Seas during glacial intervals when the world ocean level fell below the Bosphorus sill depth (-35 m). It has also been postulated that water level in the Black Sea began to rise in step with that of the Marmara and Mediterranean Seas during times when the level of the world ocean had risen above the Bosphorus sill depth (Degens and Ross 1974). Recent analyses of sediments deposited along the margins of the Black Sea suggest, however, that water-level fluctuations in the Pontic basin were somewhat more complex, with high lake levels occurring during the wet intervals of late glacial stages and low lake levels occurring during the drier intervals of early interglacials (Chepalyga 1984).

Another widely accepted hypothesis postulates that the Black Sea had always maintained a continuous outflow through the Bosphorus and Dardanelles Straits, even during the highly arid glacial intervals (Chepalyga 1984; Kvasov and Blazhchishin 1978). Essentially, this perspective assumes that precipitation and river input into the Pontic basin always exceeded any loss from local evaporation. Indeed, meltwater from the former ice sheets in Fennoscandia, northern Asia (Grosswald 1980), and the central Alps transformed the Black Sea into a giant freshwater lake a number of times during the past (Federov 1971; Ross et al. 1970), most recently during the Late Pleistocene Neoeuxinian stage of the LGM, between 25 and 18 ky BP (Arkhangel'sky and Strakhov 1938; Nevesskaya and Nevessky 1961; Nevesskaya 1965; Ross et al. 1970; Fedorov 1971).

Ryan et al. (1997) published evidence suggesting that the Black Sea became a giant freshwater lake during the LGM. This evidence included new AMS ${ }^{14} \mathrm{C}$ dates, abrupt changes in the organic carbon content, water content, and $\delta^{18} \mathrm{O}$ from core material dated approximately $7150 \mathrm{BP}$, as well as the occurrence of a widespread unconformity interpreted as an erosional surface subaerially exposed during the last glacial. The distribution of recorded depths for this unconformity implies that the surface of the freshwater lake must have fallen to levels greater than $100 \mathrm{~m}$ below its outlet. Ryan et al. (1997) inferred from this that, by about $7150 \mathrm{BP}$, the sill depth of the Bosphorus was breached by the rising world ocean, and a catastrophic flooding of the continental shelf of the Black Sea occurred (Figure 2).

Evidence that does not support the catastrophic flood hypothesis includes variously aged sapropels sampled from the eastern Mediterranean and the Black Sea. Sapropel S1 in the Aegean is generally thought to have been deposited between about 8000 and 5500 BP (Aksu et al. 1999a, b; Fontugne et al. 1994), although deposition may have lasted until 5300 BP (Rohling and de Rijk 1999). Aksu et al. (1999a) suggest that during this time, nutrient-rich freshwater from the Black Sea reduced the surface salinity of the eastern 


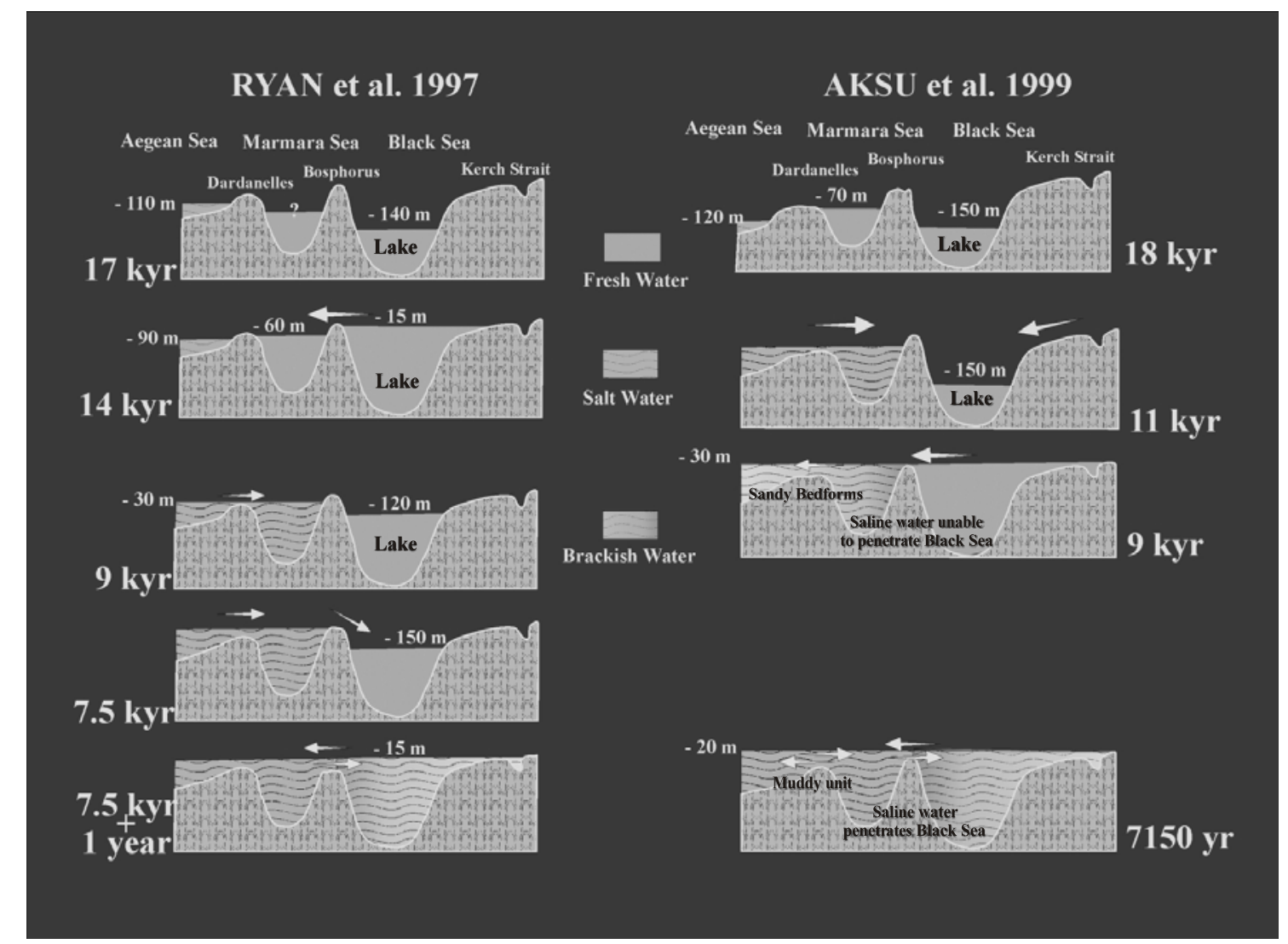

Figure 2. Alternative schemes of reconnection between the Black and Mediterranean Seas. 
Mediterranean, thereby increasing the stability between the surface and deep waters and decreasing deep circulation. As a result, high surface productivity and restricted circulation provided conditions favorable for sapropel formation. Rohling (1994), however, suggests that sapropel formation in the Black Sea started about 550 years later than it did in the eastern Mediterranean, when denser water from the Mediterranean, upon entering the Pontic basin, displaced the nutrient-rich waters in the Black Sea upward toward the surface (Calvert 1990; Calvert and Fontugne 1987). This lag is probably too large to be accounted for by the catastrophic flooding hypothesis.

\section{OBSERVATIONS}

\subsection{Acquisition and Processing of Data}

During the two campaigns on board the $R / V$ Le Suroit, a DGPS system afforded precise positioning. In some areas (for example, the dune field of Figure 3), real-time navigation processing with an accuracy of a few meters made it possible to follow parallel track lines spaced $200 \mathrm{~m}$ apart at a speed of 4 knots. The vessel was equipped with a Simrad EM 1000 swath bathymetry system, and very high resolution seismic lines were shot simultaneously using a mud-penetrator and Chirp sonar system. All data acquisition was synchronized and digitally recorded.

An EM 1000 multibeam echo-sounder provided mapped bathymetry by processing the returned echo of each sonic transmission through a selection of 68 pre-formed beams trained across a strip of sea floor effectively four times as wide as the water depth. Each beam gives a depth resolution on the order of 10 centimeters over a five by two meter footprint along the surveyed swath, and all obtained at the survey speed of 4 knots. An image of backscatter reflectance energy was generated along with the digital elevations. Navigation, bathymetry, and image data were processed and synthesized in order to plot positions automatically, and thereby produce bathymetric maps and an image mosaic.

The very high resolution seismic reflection sources were a single channel mud-penetrator with a central frequency around $2500 \mathrm{~Hz}$ and an XSTAR Chirp sonar, sweeping between 4 and $16 \mathrm{kHz}$. The digital data acquisition was done in real time on the Triton-Elics Delph PC-based system.

Coring was achieved using a Kullenberg piston core and, in some cases, a vibrocorer. 


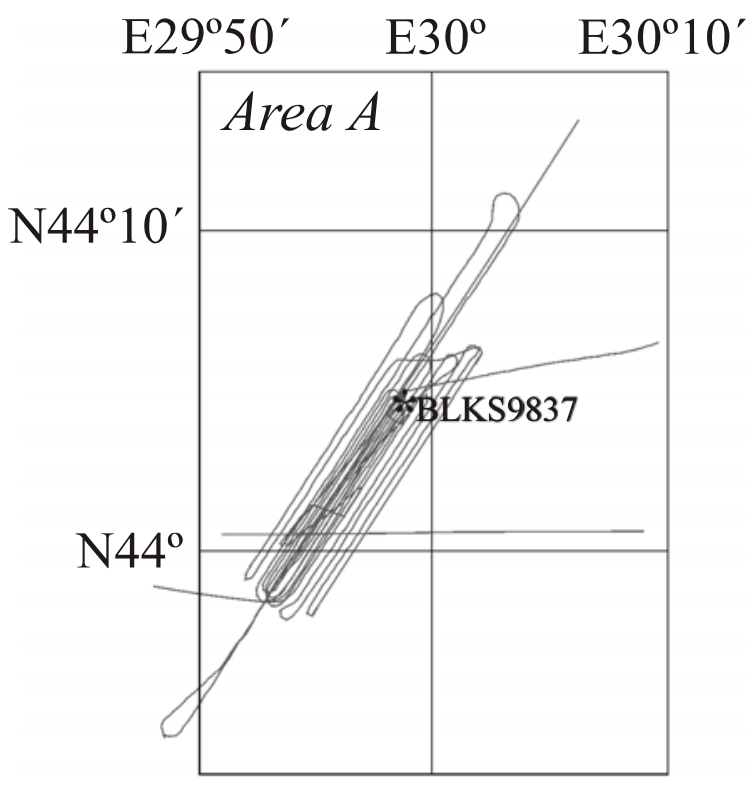

Figure 3. Map showing the location of profiles acquired on the dune field of Area A (indicated on Figure 1).

\subsection{Topography}

Bathymetry data provided by the multibeam echo-sounder are illustrated in Figure 4. Prominent in the northern half of the survey area are linear ridges four to five meters in relief with an average spacing of $750 \mathrm{~m}$. The ridges strike almost uniformly at an azimuth of $75 \pm 10^{\circ}$, they typically show asymmetrical cross-sections with the steeper sides facing to the southeast, and they reveal a length to width ratio exceeding four. Also, numerous depressions 100 to 1800 meters in diameter and 3 to 9 meters deep populate the southern half of the corridor. Depths of individual depressions are greatest at the base of their northeast walls, and they shoal to the southwest. In the center of the surveyed corridor, some depressions align within the troughs between the linear ridges.

\subsection{Subsurface Structure}

The ridges and depressions can be viewed in cross-section using high resolution seismic reflection profiles. The sub-bottom profiler and Chirp sonar provide seismic penetration to tens of meters and define layering to the sub-meter scale. The profiles indicate that the ridges in the north are asymmetrical, and with one exception, their steeper side faces to the southeast. These ridges are superimposed on a reverberant "bottomset" reflector that is sometimes conformable with subjacent strata, but in many cases truncates them (Figure 5). Although the high ground in the south has a mound-like appearance, seismic surveys show an asymmetrical cross-section with the crest and steeper slope predominantly located on the south side. The interiors of the ridges and mounds contain steeply-dipping "foreset" clinoforms with the same asymmetry and orientation as the crosssection topographic profiles. 


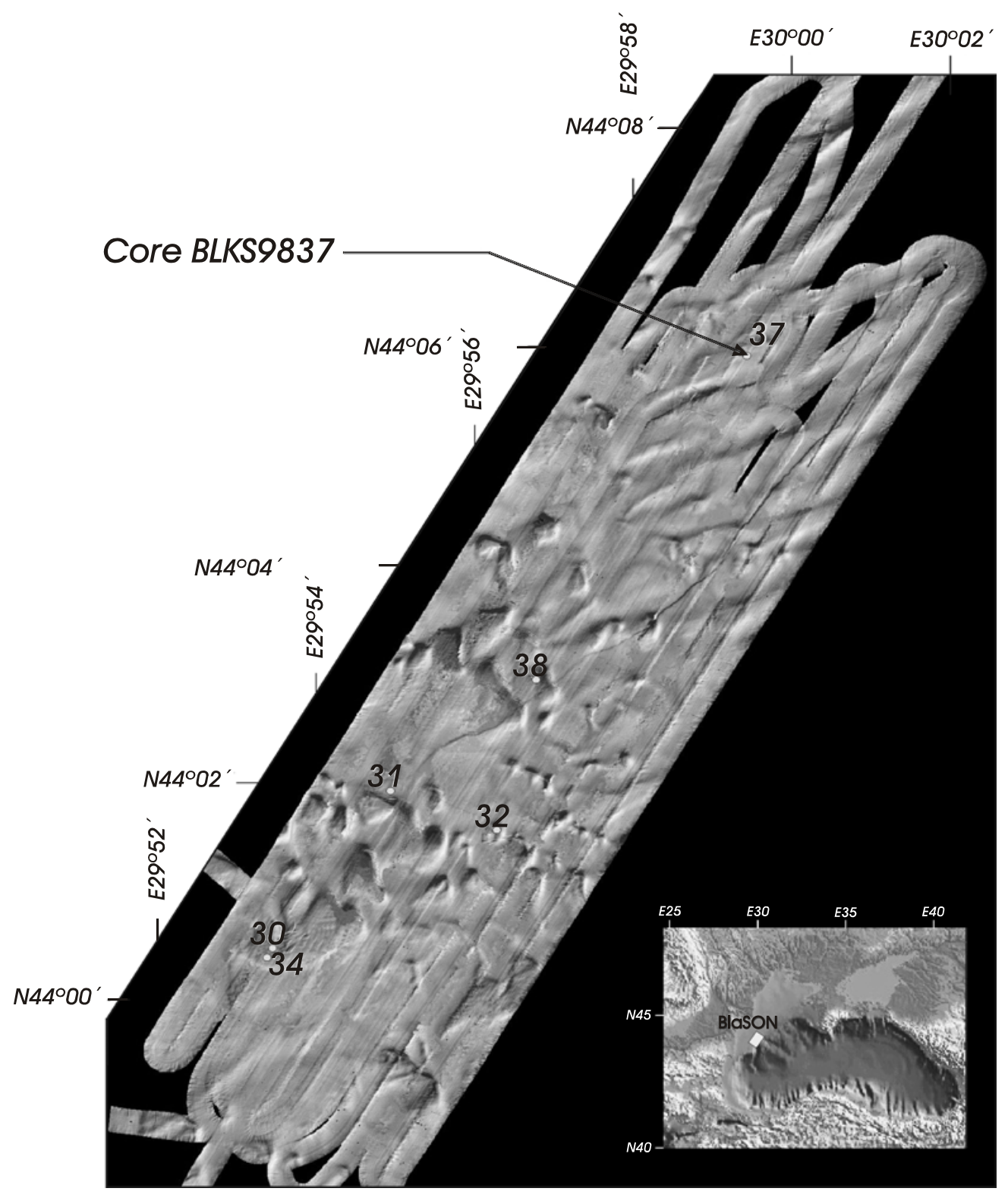

Figure 4. Multibeam bathymetry of the sand dune field and the location of core BLKS9837. 


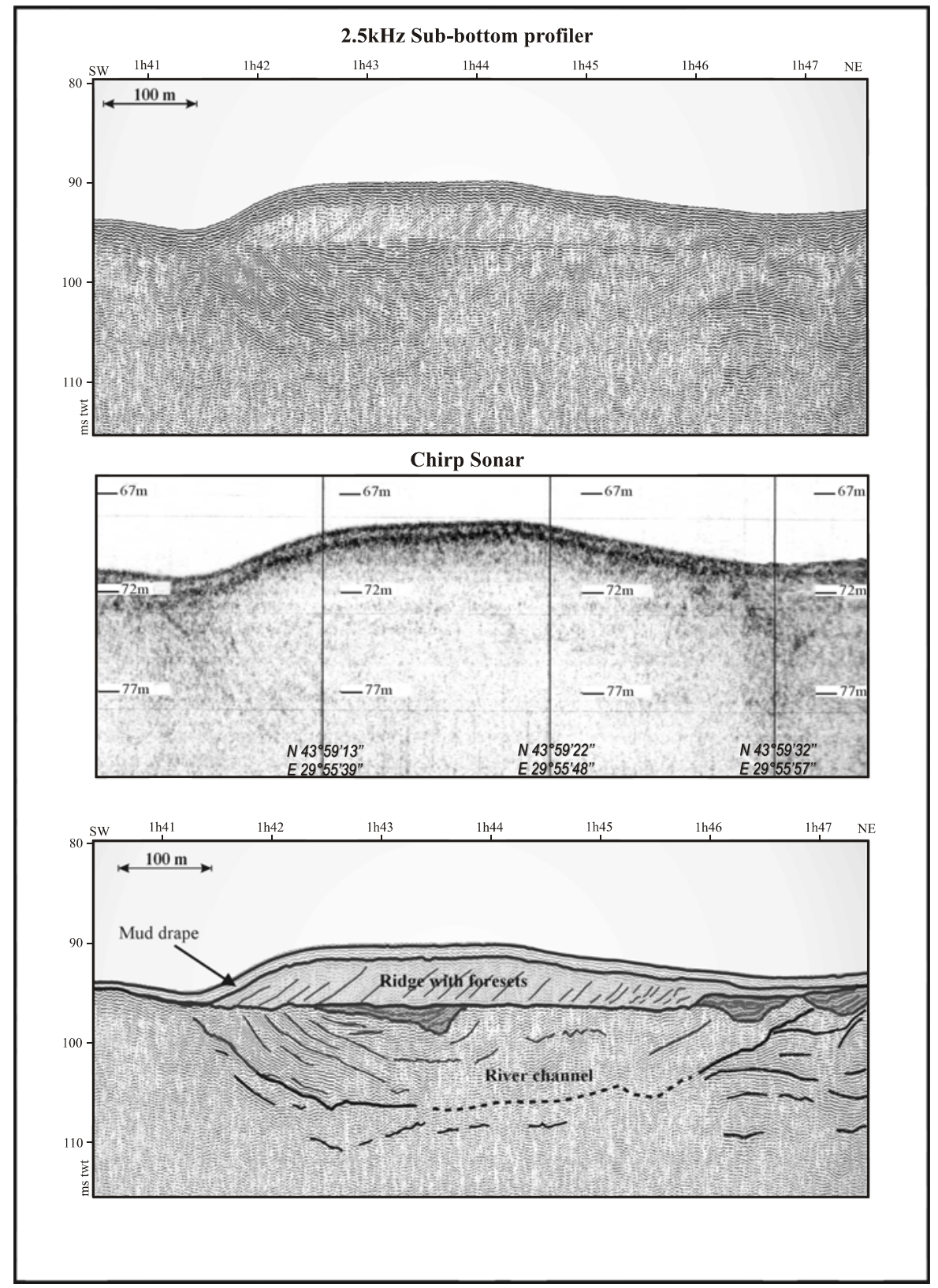

Figure 5. Seismic profiles across a sand dune. 
The ridges, mounds, and depressions of the mid and outer shelf are everywhere draped by a thin layer of sediment of remarkably uniform thickness, no more than a meter (Figure 5). The linear ridges surveyed in this study are aligned somewhat obliquely to the regional bathymetric contour and to the paleo-shoreline outlined by wave-cut terraces (Figure 6).
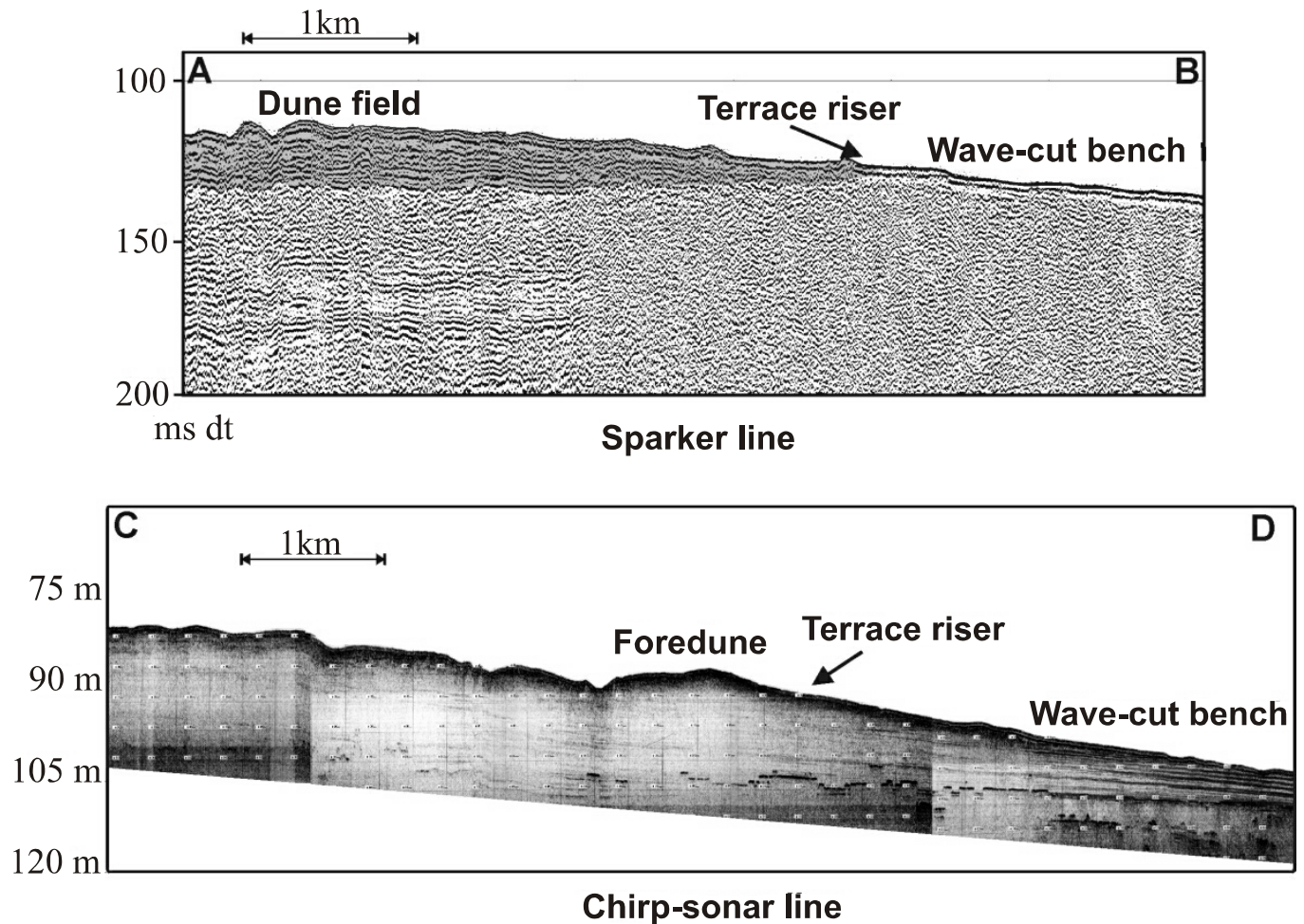

Figure 6. Seismic profiles across the wave-cut terrace.

\subsection{Sediment Cores}

Sediments obtained by coring provide ground truth for the reflection profiles. Sampling into the interior of a ridge on the dune field (core BLKS9837 taken in a water

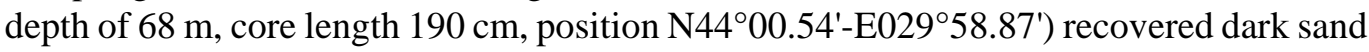
rich in opaque heavy minerals and shell fragments (Figure 7). Sampled minerals include quartz, garnet, and ilmenite. Shell fragments belong to freshwater mussels of Dreissena rostriformis distincta. Coring of the bedded sediments underlying the dunes and upon 
which they formed extracted silty red and brownish clay with thin lenses containing fresh to slightly brackish water molluscs (Dreissena and Monodacna spp., respectively). These molluscan specimens return AMS radiocarbon dates spanning the interval 8585 to 10,160 $\pm 90 \mathrm{BP}$ (without reservoir and dendrochronologic calibration).

Molluscs recovered in the cores from within the uniform surface drape reveal exclusively saltwater species, such as Mytilus edulis (also known as Mytilaster) and Cerastoderma edule. Those sampled near the base of the drape date between 6590 and $7770 \pm 80 \mathrm{BP}$.

Cores that penetrated though the drape reveal a sharp basal contact between the overlying organic mud with its marine molluscs and an underlying sand of variable thickness, rich in Dreissena sp. detritus. Recent palynological and dinocyst analyses by Speranta-Maria Popescu (Popescu et al. nd) on samples from within these cores indicate an abrupt freshwater transition during the Younger Dryas followed by an abrupt replacement of the Black Sea dinocysts by a Mediterranean population at 7150 BP.

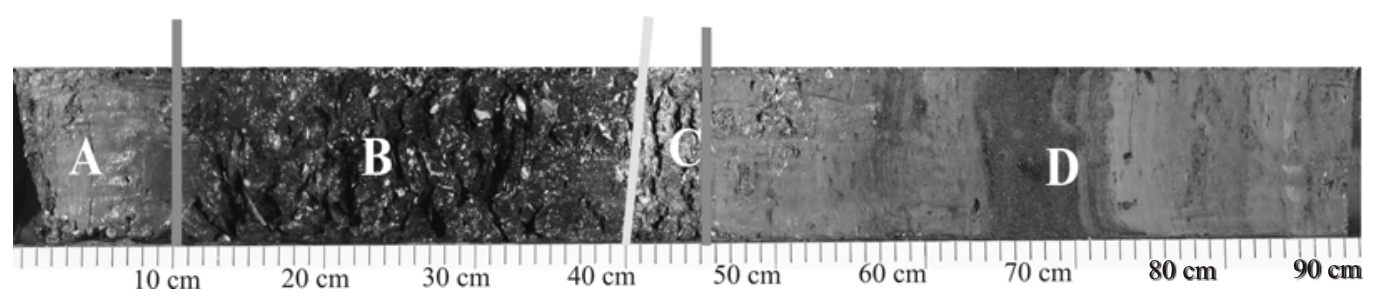

Figure 7. Core BLKS9837 (N4400.54'-E2958.87') recovered from dune field; A = layer with Modulus dated from 3000 BP to present; B = layer with Mytilus edulis dating between 6900 and 3000 BP; C = layer with Dreissena sp., the youngest dating $7150 \mathrm{BP}$.

\section{DISCUSSION}

The sand dune fields and associated wave-cut terrace are interpreted as coastal zone relics that have persisted since 9680 to $8360 \mathrm{BP}$. At that time, a wave-cut terrace presently at $-100 \mathrm{~m}$ with dunes and pans between -80 and $-65 \mathrm{~m}$ would have lain well below the level of the external ocean (Fairbanks 1989). A lake could have existed below global sea level only if the Bosphorus barrier was higher than the external ocean, thereby preventing outflow. Burial of the dunes and pans by a drape of mud is not sufficient to imply a sudden infilling of the depression once the Bosphorus barrier was breached, but considering the evidence of (1) an abrupt transition from shell hash (a very condensed layer with brackish fauna) to mud, and (2) the impressive preservation of dunes and pans with no preferential 
infilling of the depression, a rapid terminal transgression of the Black Sea seems a compelling interpretation. The Caspian Sea, which appears to have experienced similar phenomena (with the exception of the last reconnection), reveals in the Iranian coastal regions of Mazandaran and Gilan comparable sand dunes on the terrestrial surface as high as $20 \mathrm{~m}$ that lie parallel to the seashore and which contain sandy particles and fragments of shells. The relic Black Sea dunes are occasionally cut across by aeolian deflation, which testifies to a previous lowstand.

Water-level fluctuations in the Black Sea appear to be directly linked to climate variability (Kvasov 1975; Svitoch et al. 2000). The Caspian Sea, another enclosed basin, reacted similarly. When not connected to the Mediterranean via the Black Sea, it reached highstands and achieved outflow in cold periods and drew down to lowstands through evaporation in warm periods. When the Mediterranean Sea penetrated the Dardanelles Strait at ca. 12,000 BP, the level of the Marmara was below its outlet (Aksu et al. 1999b, 2002b).

Whether catastrophic flooding is hydraulically possible remains open to question. Lane-Serff et al. (1997) used a hydraulic model for the events following the connection of the Black Sea to the Mediterranean and assumed that the sill cross-section has remained more-or-less unchanged. They showed that significant freshwater outflow from the Black Sea occurred only 500-1000 years after sea level in the Mediterranean reached the Bosphorus sill depth. A two-layer exchange between the two seas was initiated when an upper limit to the water flux was able to pass over the sill. This delay corresponds in order of magnitude to the lag between the onset of sapropel deposition in the Mediterranean and that in the Black Sea. Furthermore, they also demonstrated that it took 2500-3500 years for the bulk of the freshwater in the Black Sea to be replaced by salty Mediterranean water and for euryhaline-marine conditions to be established. This period corresponds to the time of eastern Mediterranean sapropel deposition.

Debate continues about whether a catastrophic flood in the Black Sea significantly impacted the habitation, migration, and cultural practices of the European Neolithic population. The archaeological interpretations presented by Ryan and Pitman (1998) depend upon the principal archaeological assumption that after the onset of agriculture, the ancient Near East suffered a drought that forced the first farmers to find refuge in a more hospitable climate, that of the pre-flood Black Sea coast. Kalis et al. (2003) suggest that a more realistic picture of the Neolithic diaspora into Europe consists of various waves, currents, and eddies of people, bringing animals and plants. In some areas, an influx of migrating farmers replaced sparse local foraging populations with Neolithic agricultural communities. Elsewhere, early farming communities appeared as isolated pioneer outposts within a multicultural landscape of foragers and farmers. 


\section{CONCLUSION}

Recent surveys carried out on the northwestern continental shelf of the Black Sea imply that the early Holocene lake level rose on the shelf to at least the -40 to $-30 \mathrm{~m}$ isobath as evidenced by the landward limit of the Dreissena layer, which is characteristic of freshwater conditions. This rise in freshwater level is consistent with interpretations of the Pontic basin as an important catchment for meltwater drained from ice caps during Melt Water Pulse 1. It is possible that the lake, having filled with freshwater at this time, rose to the level of its outlet and spilled into the Mediterranean. However, in the mid-Holocene, at $7150 \mathrm{BP}$, the onset of salt water conditions is clearly evidenced in the Black Sea. From these observations, Ryan et al. (1997) came to the conclusion that the Black Sea could have been filled by saltwater cascading from the Mediterranean.

Despite discussions to the contrary, recent IFREMER seismic surveys indicate the presence of well preserved drowned beaches, sand dunes, and soils supporting the interpretations of Ryan and Pitman that the Black Sea was rapidly filled with marine water from the Mediterranean during the mid-Holocene.

\section{ACKNOWLEDGMENTS}

Our research was supported by the French Ministry of Foreign Affairs in the context of a bilateral collaboration between France and Romania, and continued by a European project of the 5 th framework program called ASSEMBLAGE. We thank Nicolae Panin for the important role he played in this collaboration. We also thank William Haxby, Eliane Le Drezen, and Alain Normand for their work in multibeam data processing; Hervé Nouzé and Hervé Gillet for seismic processing; and the crew of the vessel Le Suroît. We also thank William B.F. Ryan and Candace Major for having shared their ideas at the beginning of these oceanic cruises and for their help in core dating. Appreciation is expressed to Renée Hetherington for her help in editing.

\section{ENDNOTES}

1. The abbreviation BP means radiocarbon years before present (1950) with neither correction for reservoir age nor calibration to calendar years. In Ryan et al. (1997) and Ryan and Pitman (1998), ages were expressed in calendar years, with 7500 calBP (= 5550 BC) equivalent to $7100 \mathrm{BP}$. 


\section{REFERENCES}

Abrajano, T., A.E. Aksu, R.N. Hiscott, and P.J. Mudie

2002 Aspects of carbon isotope biogeochemistry of late Quaternary sediments from the Marmara Sea and Black Sea. Marine Geology 190:151-164.

Aksu, A.E., T. Abrajano, P.J. Mudie, and D. Yaşar

1999a Organic geochemical and palynological evidence for terrigenous origin of the organic matter in Aegean Sea sapropel S1. Marine Geology 153:303-318.

Aksu, A.E., R.N. Hiscott, and D. Yaşar

1999b Oscillating Quaternary water levels of the Marmara Sea and vigorous outflow into the Aegean Sea from the Marmara Sea-Black Sea drainage corridor. Marine Geology 153: 275-302.

Aksu, A.E., R.N. Hiscott, D. Yaşar, F.I. Işler, and S. Marsh

2002a Seismic stratigraphy of Late Quaternary deposits from the southwestern Black Sea shelf: evidence for non-catastrophic variations in sea-level during the last 10 000 yr. Marine Geology 190:61-94.

Aksu, A.E. R.N. Hiscott, M.A. Kaminski, P.J. Mudie, H. Gillespie, T. Abrajano, and D. Yaşar

2002b Last glacial-Holocene paleoceanography of the Black Sea and Marmara Sea: stable isotopic, foraminiferal and coccolith evidence. Marine Geology 190:119-149.

Aksu, A.E., R.N. Hiscott, P.J. Mudie, A. Rochon, M.A. Kaminski, T. Abrajano, and D. Yaşar

2002c Persistent Holocene outflow from the Black Sea to the Eastern Mediterranean contradicts Noah's Flood Hypothesis. GSA Today 12(5):4-10.

Algan O., N. Çağatay, A. Tchepalyga, D. Ongan, C. Eastoe, and E. Gökaşan

2001 Stratigraphy of the sediment infill in Bosphorus Strait: water exchange between the Black and Mediterranean Seas during the last glacial Holocene. Geo-Marine Letters, 20(4):209-218.

Arkhangel'sky, A.D., and N.M. Strakhov

1938 Geologicheskoe stroenie i istoriia razvitiia Chernogo moria [Geological Structure and History of the Black Sea]. Izdatel'stvo Akademiia Nauk SSSR, Moscow and Leningrad. (In Russian)

Bard, E., B. Hamelin, R.G. Fairbanks, and A. Zindler

1990 Calibration of the ${ }^{14} \mathrm{C}$ timescale over the past 30,000 years using mass spectrometric $\mathrm{U}-\mathrm{Th}$ ages from Barbados corals. Nature 345(6274):405-410.

Bondar, C.

1998 Hydromorphological relation characterizing the Danube river mouths and the coastal zone in front of the Danube delta. Geo-Eco-Marina 3:99-102.

Calvert, S.E

1990 Geochemistry and origin of the Holocene sapropel in the Black Sea. In Facets of Modern Biogeochemistry, V. Ittekkot, S. Kempe, W. Michaelis, and A. Spitzy, eds, pp. 326-352. SpringerVerlag, Berlin.

Calvert, S.E. and M.R. Fontugne

1987 Stable carbon isotopic evidence for the marine origin of the organic matter in the Holocene Black Sea sapropel. Chemical Geology 66(3-4):315-322.

Chepalyga, A.L.

1984 Inland sea basins. In Late Quaternary Environments of the Soviet Union, A.A. Velichko, ed., H.E. Wright, Jr., and C.W. Barnowsky, eds English edition, pp 229-247. University of Minnesota Press, Minneapolis.

Degens, E.T., and D.A. Ross, eds.

1974 The Black Sea-Geology, Chemistry, and Biology. Memoir 20, American Association of Petroleum Geologists, Tulsa. 
Evsylekov, Y.D. and K.M. Shimkus

1995 Geomorphological and neotectonic development of outer part of continental margin to the south of Kerch Strait. Oceanology 35:623-628.

Fairbanks, R.G.

1989 A 17,000-year glacio-eustatic sea level record: influence of glacial melting rates on the Younger Dryas event and deep-ocean circulation. Nature 342(6250):637-642.

Fedorov, P.V.

1971 Postglacial transgression of the Black Sea. International Geology Review 14(2):160-164.

Fontugne, M.R. M. Arnold, L. Labeyrie, M. Paterne, S.E. Calvert, and J.-C. Duplessy

1994 Paleoenvironment, sapropel chronology and Nile river discharge during the last 20,000 years as indicated by deep-sea sediment records in the eastern Mediterranean. In Late Quaternary Chronology and Paleoclimates of the Eastern Mediterranean, O. Bar-Yosef and R.S. Kra, eds., pp. 75-88. RADIOCARBON and the American School of Prehistoric Research, Tucson, Arizona, and Cambridge, Massachusetts.

Gökaşan, E., E. Demirbağ, F.Y. Oktay, B. Ecevitoğlu, M. Şimşek, and H. Yüce

1997 On the origin of the Bosphorus. Marine Geology 140:183-199.

Grosswald, M.G.

1980 Late Weichselian ice sheet of northern Eurasia. Quaternary Research 13(1):1-32.

Hodder, I.

1990 The Domestication of Europe: Structure and Contingency in Neolithic Societies. Blackwell Publishers, Oxford.

Kalis, A.J., J. Merkt, and J. Wunderlich

2003 Environmental changes during the Holocene climatic optimum in central Europe - human impact and natural causes. Quaternary Science Reviews 22(1):33-79.

Kvasov, D.D.

1975 Pozdnechetvertichnaia istoriia krupnykh ozer i vnutrennikh morei Vostochnoi Evropy [The Late Quaternary History of the Large Lakes and Inland Seas of Eastern Europe]. Nauka, Moscow.

Kvasov, D.D. and A.I. Blazhchishin

1978 The key to sources of the Pliocene and Pleistocene glaciation is at the bottom of the Barents Sea. Nature 273(5658):138-140.

Lane-Serff, G.F., E.J. Rohling, H.L. Bryden, and H. Charnock

1997 Postglacial connection of the Black Sea to the Mediterranean and its relation to the timing of sapropel formation. Paleoceanography 12(2):169-174.

Major, C.O.

1994 Late Quaternary Sedimentation in the Kerch Area of the Black Sea Shelf: Response to Sea Level Fluctuation. BA Thesis, Wesleyan University, Middletown, Connecticut.

Muramoto, J.A., S. Honjo, B. Fry, B.J. Hay, R.W. Howarth, and J.L. Cisne

1991 Sulfur, iron and organic carbon fluxes in the Black Sea-sulfur isotopic evidence for origin of sulfur fluxes. In Black Sea oceanography; results from the 1988 Black Sea Expedition. Deep-Sea Research Part A. Oceanographic Research Papers 38(Supplement 2A): S1151-S1187.

Nevesskaya, L.A.

1965 Pozdnechetvertichnye dvustvorchatye molliuski Chernogo Moria, ikh sistematika i ekologiia [Late Quaternary Bivalve Molluscs of the Black Sea, their Systematics and Ecology]. Trudy Paleontologicheskogo Instituta Akademii Nauk SSSR 105. Nauka, Moscow.

Nevesskaya, L.A., and Yu.N. Nevessky

1961 O sootnoshenii karangatskikh i novoevksinskikh sloev v pribrezhnykh raionakh Chernogo moria [Correlation between the Karangatian and Neoeuxinian layers in littoral regions of the Black Sea]. 
Panin, N.

Doklady Akademii Nauk SSSR 137(4):934-937.

1997 On the geomorphologic and geologic evolution of the river Danube-Black Sea interaction zone. GeoEco-Marina 2:31-40.

Popescu, S.-M., M.J Head,. J.-P. Suc, G. Lericolais, and M.N. Çağatay

nd Rapid flooding of the Black Sea at 7,160 yrs BP after progressive salinity increase since 12,800 yrs BP. Ms. Submitted for publication.

Rohling, E.J.

1994 Review and new aspects concerning the formation of eastern Mediterranean sapropels. Marine Geology 122:1-28.

Rohling, E.J., and S. de Rijk

1999 Holocene Climate Optimum and Last Glacial Maximum in the Mediterranean: the marine oxygen isotope record. Marine Geology 153:57-75.

Ross, D.A., E.T. Degens, and J. MacIlvaine

1970 Black Sea: recent sedimentary history. Science 170(3954):163-165.

Ryan, W., and W.C. Pitman

1998 Noah's Flood: The New Scientific Discoveries About the Event that Changed History. Simon \& Schuster, New York.

Ryan, W.B.F., W.C. Pitman, III , C.O. Major, K. Shimkus, V. Moskalenko, G.A. Jones, P. Dimitrov, N. Görür, M. Sakınç and H. Yüce

1997 An abrupt drowning of the Black Sea shelf. Marine Geology 138:119-126.

Ryan, W.B.F., C.O. Major, G. Lericolais, and S.L. Goldstein

2003 Catastrophic flooding of the Black Sea. Annual Review of Earth and Planetary Science 31:525-554. Scholten, R.

1974 Role of the Bosporus in Black Sea chemistry and sedimentation. In The Black Sea - Geology, Chemistry, and Biology, E.T. Degens and D.A. Ross, eds, pp. 115-126. American Association of Petroleum Geologists, Memoir 20, Tulsa, Oklahoma.

Svitoch, A.A., A.O. Selivanov, and T.A. Yanina

2000 Paleohydrology of the Black Sea Pleistocene basins. Water Resources 27:594-603. 
